\title{
The effect of dairy cows grazing in early spring on phosphorus loss in overland flows post first and second grazing events
}

\author{
D A McConnell ${ }^{1,3}$, C P Ferris $^{1}$, D G Doody ${ }^{2}$, C T Elliott ${ }^{3}$, D I Matthews ${ }^{2}$
}

${ }^{1}$ Agri-Food and Biosciences Institute, Hillsborough, Co Down, United Kingdom, ${ }^{2}$ Agri-Environment Branch, Agri-Food and Biosciences Institute, Belfast, United Kingdom, ${ }^{3}$ Queen's University Belfast, Belfast, United Kingdom

Email: debbie.mcconnell@afbini.gov.uk

Introduction Early season grazing has a number of benefits on dairy farms, including reducing silage requirements, reducing the quantity of slurry in stores, and encouraging good sward development. However, soil moisture levels can be high in early spring, thus increasing the risk of soil surface damage. This, combined with the removal of herbage by grazing cows may increase the risk of phosphorus (P) export to waterways via overland flow pathways. In view of the contribution of $\mathrm{P}$ to eutrophication of waters in Northern Ireland, early spring grazing may present a risk. Thus, the aim of this experiment was to examine the effect of grazing intensity in spring on $\mathrm{P}$ losses via overland flow.

Materials and methods Four treatments (Table 1) were examined in a randomised block design experiment. Treatments were imposed during the first grazing in the spring $\left(23^{\text {rd }}\right.$ February), and comprised swards being ungrazed (UG), lightly grazed (LG) or heavily grazed (HG). A second grazing event $(-G)$ took place six weeks later $\left(6^{\text {th }}\right.$ April). A fourth treatment (UG-UG) was not grazed during either grazing event. Sixteen plots (each measuring $3 \times 7 \mathrm{~m}$ ) were established in four blocks on a permanent pasture on a north facing slope (average slope 6.5\%). Blocks were separated by buffer strips, and were enclosed within an area measuring $35 \times 38 \mathrm{~m}$. Pre-grazing sward heights for the first and second grazing events were $5.2 \mathrm{~cm}$ and $6.9 \mathrm{~cm}$ respectively. This area was grazed by ten lactating dairy cows (average liveweight, $650 \mathrm{~kg}$ ) fitted with excreta collection bags. During the first grazing event the ten cows had access to the LG- and HG- plots for a period of 90 minutes, before being removed. Cows were returned to the site later on the same day and had access to the HG- plots for a further 90 minutes. Following the first grazing event average sward height was $4.6 \mathrm{~cm}$ and $4.0 \mathrm{~cm}$ for LG- and HG- plots respectively. During the second grazing event cows had access to the UG-G, LG-G and HG-G plots for 120 minutes with plots grazed to a mean residual sward height of $3.0 \mathrm{~cm}$. The soil was a Brown Earth clay loam of Olsen P content $39.2 \mathrm{mg} / 1$ (Index 3). Average volumetric soil moisture content was $63 \%$ and $56 \%$ for the first and second grazing events respectively. Overland flow was generated at 2 and 16 days post grazing using two portable rainfall simulators. Rainfall was simulated at a rate of $40 \mathrm{~mm} / \mathrm{hr}$ (return period $>1$ in $50 \mathrm{yrs}$ ). Runoff was generated for a 30 minute period and collected in $3 \mathrm{x} 10 \mathrm{minute}$ discrete samples. Soluble reactive phosphorus (SRP), total soluble phosphorus (TSP) and total phosphorus (TP) were determined using standard colorimetry techniques. Particulate phosphorus (PP) was inferred as the difference between TP and TSP. Differences between each of the four treatments were analysed by ANOVA using SPSS software, with each of the first and second grazing events analysed separately. Significance of differences between treatments were determined by Least Significant Difference.

Table 1 Treatments imposed during the first and second grazing events

\begin{tabular}{lll}
\hline Treatment & First Grazing (23.02.09) & Second Grazing (06.04.09) \\
\hline UG-G & Ungrazed & Grazed \\
LG-G & Light Grazing & Grazed \\
HG-G & Heavy Grazing & Grazed \\
UG-UG & Ungrazed & Ungrazed \\
\hline
\end{tabular}

Results Average P concentrations measured in overland flow are presented in Table 2. Treatment had no effect on SRP or TSP losses during either the first or second grazing events $(\mathrm{P}>0.05)$. During the first grazing event light grazing (LG) had no significant effect on either TP or PP losses, compared to the ungrazed treatments $(\mathrm{P}>0.05)$, while losses were higher with the heavy grazing $(\mathrm{HG})$ treatment $(\mathrm{P}<0.05)$. When swards were grazed in early April, TP and PP losses were higher $(\mathrm{P}<0.001)$ in treatments which had been grazed in early season (LG-G and HG-G), compared to those that were not (UG$\mathrm{G})$. The numerically higher TP and PP losses recorded in all treatments during the second grazing event reflects a higher volumetric soil moisture levels $(68.1 \%)$ at the time when runoff was generated, a consequence of a period of heavy rainfall post grazing.

Table 2 Average P concentration $(\mu \mathrm{g} / \mathrm{l})$ in overland flow during the first and second grazing events

\begin{tabular}{|c|c|c|c|c|c|c|c|c|c|c|c|c|}
\hline \multicolumn{7}{|l|}{ First grazing event } & \multicolumn{6}{|c|}{ Second grazing event } \\
\hline & UG-G & LG-G & HG-G & $\begin{array}{l}\text { UG- } \\
\text { UG }\end{array}$ & S.E.M. & sig. & UG-G & LG-G & HG-G & $\begin{array}{l}\text { UG- } \\
\text { UG }\end{array}$ & S.E.M. & sig. \\
\hline Soluble Reactive $\mathrm{P}$ & 172 & 150 & 188 & 154 & 19.6 & NS & 132 & 127 & 139 & 106 & 11 & NS \\
\hline Total Soluble P & 222 & 217 & 249 & 197 & 21.3 & NS & 185 & 176 & 192 & 153 & 11 & NS \\
\hline Total P & $673^{\mathrm{a}}$ & $835^{\mathrm{ab}}$ & $993^{\mathrm{b}}$ & $634^{\mathrm{a}}$ & 82.5 & 0.05 & $1363^{\mathrm{a}}$ & $1984^{\mathrm{b}}$ & $2373^{\mathrm{b}}$ & $1035^{\mathrm{a}}$ & 182 & 0.001 \\
\hline Particulate P & $450^{\mathrm{a}}$ & $618^{\mathrm{ab}}$ & $744^{\mathrm{b}}$ & $437^{\mathrm{a}}$ & 81.3 & 0.05 & $1168^{\mathrm{a}}$ & $1805^{\mathrm{b}}$ & $2103^{\mathrm{b}}$ & $867^{\mathrm{a}}$ & 175 & 0.001 \\
\hline
\end{tabular}

Conclusions Heavy grazing in early spring increased the risk of P losses (TP and PP), while 'well managed' light grazing had no effect on P losses. However, there was evidence of a carry-over effect, with early spring grazing resulting in increased $\mathrm{P}$ losses during a later grazing event, although these losses were measured at a time when soil moisture levels were high.

Acknowledgements DMcC acknowledges receipt of a DARD postgraduate studentship. Study funded by DARD and AgriSearch. 